\title{
Evaluating the diagnostic accuracy of ultrasonography in differential diagnosis of adnexal tumours
}

\author{
AGATA SMOLEŃ1ª-G, NORBERT STACHOWICZ², в , ARTUR CZEKIERDOWSKI², A, в, D, F, G \\ ${ }^{1}$ Chair and Department of Epidemiology and Clinical Research Methodology, Medical University of Lublin \\ ${ }^{2}$ First Department and Clinic of Gynecological Oncology and Gynaecology, Medical University of Lublin
}

A - Study Design, B - Data Collection, C - Statistical Analysis, D - Data Interpretation, E - Manuscript Preparation,

$\mathbf{F}$ - Literature Search, $\mathbf{G}$ - Funds Collection

Summary Background. Ultrasound is a crucial diagnostic procedure in the structural assessment of lesser pelvis organs. It is useful in preliminary diagnosis pertaining to a tumour's potential malignancy, and visual staging of lesser pelvis neoplasms. Objectives. Evaluation of the diagnostic benefits of grey-scale ultrasonography, colour and spectral Doppler, and three-dimensional ultrasonography in differential diagnosis of adnexal tumours.

Material and methods. From a total of 637 patients diagnosed with an ovarian tumour, $202(31.7 \%)$ women presented with malignant tumours and $435(68.3 \%)$ with benign. The patients were classified into the following categories according to FIGO: 52 patients in stage I, 15 in stage II, and the rest in stage III (127 patients) or stage IV (8 patients).

Results. The uppermost test accuracy for the superior discriminating threshold value was reported in the case of the semiquantitative analysis of the "Colour" score $-81 \%$, and the presence of central vascularity. Other factors included: age, bilateral tumour location with $75 \%$ specificity, menopausal status, and presence of papillary projections $-74 \%$. For VFI and VI indices set values amounted to $74 \%$ and $73 \%$, respectively. Blood flow assessments measured with PI and RI parameters during spectral Doppler imaging do not appear to present clinically significant diagnostic value.

Conclusions. The following parameters have to be considered in initial differentiating diagnostics of adnexal tumours: a) semiquantitative analysis of the "Colour" characteristic and vascular localization in 2D Doppler ultrasound, b) morphological assessment of the tumour in 2D colour Doppler ultrasound, d) evaluation of vascular flow in 3D ultrasound with the implementation of sonoangiography, vascularization index VI, and vascularization-flow index VFI.

Key words: ultrasound, ovarian cancer, adnexal tumours.

Fam Med Prim Care Rev 2016; 18(3): 340-344

\section{Background}

Ultrasound is the main initial imaging test in the diagnostics and monitoring of ovarian cancer. It enables the physician to make an approximate diagnosis concerning tumour grade and staging in the lesser pelvis. One of the advantages of ultrasound is its safety and the ability to perform the test multiple times [1-4].

Grayscale ultrasound imaging, otherwise called "B-Mode" (brightness, modulation), is the basic ultrasound imaging method, and enables a $2 \mathrm{D}$ visualization of the examined organs.

The colour Doppler ultrasound method visualizes blood flow in the pathological changes of the ovaries, thus enabling to a greater degree the distinguishing of benign and malignant processes. Semi-quantitative analysis of blood perfusion in an adnexal tumour requires the measurement of the pulsation (PI) and resistance (RI) indices. Additionally, in initial ovarian tumour grading, mean TAMXV (time averaged maximum velocity) and mean PSV (peak systolic velocity) values are used $[5,6]$.

Implementing the colour scale to mark the direction of blood flow in the colour Doppler (CD) method expanded the capabilities of ultrasound imaging. The main advantage of this method is the ability to visualize very minuscule vessels. It also enables the visualization of the pathological vasculature of lesser pelvis tumours in women, whereas the technique called colour Doppler energy (CDE) or power an- gio Doppler visualizes blood cell flow in colour, thus creating an image of very minuscule vessels by the assessment of the "energy" of blood cell flow and not direction and speed.

3D imaging and digital image analysis are used in creating computed tomography images, which enable the proper evaluation of lesions that are further away from the head of the ultrasound machine. This imaging technique visualizes the spatial arrangement of very small vessels in solid areas and septi of the neoplastic lesion. Another advantage of 3D ultrasound is the ability to precisely measure the volume of small lesions in the lesser pelvis, regardless of their shape $[3,4,6]$. The following indices are automatically calculated: vascularity index $(\mathrm{VI})$, flow index $(\mathrm{FI})$ and vascular flow index (VFI) $[1,8]$. Ultrasound imaging lets us describe the dimensions and volume of the tumour, its localization, and can also confirm that the lesion originates from the ovum. In many cases ultrasound diagnostics can be used to evaluate the extent of the neoplastic process, i.e. infiltration of surrounding tissues, as well as to search for metastasis of other malignant tumours to the ovum, or metastatic lesions of ovarian cancer to other organs located in the abdomen $[2,3]$.

\section{Objectives}

This study aims to evaluate the diagnostic accuracy of ultrasound diagnostics in grayscale, colour Doppler mode, and 3D ultrasonography in differentiating adnexal tumours. 


\section{Material and methods}

From a total of 637 patients diagnosed with an ovarian tumour, $202(31.7 \%)$ women presented with malignant tumours and $435(68.3 \%)$ with benign. The patients were classified into the following categories according to FIGO: 52 patients in stage I, 15 in stage II, and the rest in stage III (127 patients) or stage IV (8 patients). In the histological evaluation of tumour differentiation according to WHO, 20 tumours were graded as G1, 81 as G2, 90 as G3, and 11 cases were left unrated. The diagnosis was confirmed histopathologically in all cases.

2D gray scale ultrasound, together with flow evaluation in colour and spectral Doppler ultrasound and 3D sonography with shape measurement in the $\mathrm{VOCAL}^{\mathrm{TM}}$ (with angiohistogram function) program were analyzed. For every patient, the clinical and ultrasound characteristics listed in Table 1 were evaluated.

Table 1. Characteristics of selected clinical and ultrasound characteristics in the studied group

\section{Evaluated characteristics}

\begin{tabular}{|l|}
\hline Age \\
\hline menopause status \\
\hline body mass index BMI $\left(\mathrm{kg} / \mathrm{m}^{2}\right)$ \\
\hline location of the tumour (one side/ both sides) \\
\hline histologic type according to $\mathrm{WHO}$ \\
\hline stage according to FIGO \\
\hline tumour segmentation $(>3 \mathrm{~mm}$ or none) \\
\hline solid elements in the tumour (present/none) \\
\hline endophytic growths in the tumour (> $3 \mathrm{~mm}$ or none) \\
\hline largest tumour size (mm) \\
\hline tumour volume (mL) \\
\hline vessel location (central/peripheral/none) \\
\hline
\end{tabular}

\begin{tabular}{|l|}
\hline Colour according to IOTA \\
\hline pulsation index $\mathrm{PI}$ \\
\hline resistance index $\mathrm{RI}$ \\
\hline peak systolic velocity PSV $(\mathrm{cm} / \mathrm{S})$ \\
\hline mean value of flow velocity TAMXV $(\mathrm{cm} / \mathrm{S})$ \\
\hline vascularization index $\mathrm{VI}$ \\
\hline flow index FI \\
\hline vascularization flow index $\mathrm{VFI}$ \\
\hline
\end{tabular}

\section{Results}

The diagnostic usefulness of the analyzed single tests for the threshold value best distinguishing between malignant and benign tumour, as well as predictive values of the most commonly cited parameters for the threshold values in discriminating between malignant and benign adnexal tumours are presented in Table 2. The evaluation was conducted with consideration of the number of truly positive (TP), false positive (FP), false negative (FN) and truly negative (TN) results, together with the prognostic values, i.e. sensitivity (SENS), specificity (SPEC), likelihood ratio (LR+ and LR-), positive and negative predictive values (PPV and NPV), and diagnostic accuracy (ACC).

The highest value of test precision for the most discriminative threshold value has been concluded in the case of a semiquantitative evaluation of the "colour" characteristic, $81 \%$, and for the central localization of vascularization, $79 \%$. Age, bilateral location of the tumour with a probability of $75 \%$, postmenopausal status and endophytic lesions were other criteria taken into account. The VFI index amounted to $74 \%$, whereas the $\mathrm{VI}$ index presented a value of $73 \%$. The blood flow PI and RI indices acquired during spectral Doppler ultrasound examination did not prove useful for diagnostics. For the threshold values of $\mathrm{PI}$ and RI most commonly quoted in the literature, the predictive values were low. The calculated values of the area under the ROC (AUROC) curve with a standard error and a $95 \%$ confidence interval $(95 \% \mathrm{Cl})$ for the parameters analyzed are shown in Table 3.

\begin{tabular}{|c|c|c|c|c|c|c|c|c|c|c|c|}
\hline $\begin{array}{l}\text { Parameter (optimal } \\
\text { threshold) }\end{array}$ & $\mathrm{TP}$ & FP & FN & TN & SENS & SPEC & LR+ & LR- & PPV & NPV & $\mathrm{ACC}$ \\
\hline $\begin{array}{l}\text { Age } \\
\text { (55 years) }\end{array}$ & 103 & 58 & 99 & 377 & 0.51 & 0.87 & 3.82 & 0.57 & 0.64 & 0.79 & 0.75 \\
\hline $\begin{array}{l}\text { BMl } \\
\left(25 \mathrm{~kg} / \mathrm{m}^{2}\right)\end{array}$ & 112 & 115 & 90 & 320 & 0.55 & 0.74 & 2.10 & 0.61 & 0.49 & 0.78 & 0.68 \\
\hline $\begin{array}{l}\text { MNP } \\
\text { (post-mnp) }\end{array}$ & 120 & 85 & 82 & 350 & 0.59 & 0.80 & 3.04 & 0.50 & 0.59 & 0.81 & 0.74 \\
\hline Both sides & 100 & 56 & 102 & 379 & 0.50 & 0.87 & 3.85 & 0.58 & 0.64 & 0.79 & 0.75 \\
\hline $\mathrm{SEPT}>3 \mathrm{~mm}$ & 158 & 188 & 44 & 247 & 0.78 & 0.57 & 1.81 & 0.38 & 0.46 & 0.85 & 0.64 \\
\hline $\mathrm{PAP}>3 \mathrm{~mm}$ & 91 & 55 & 111 & 380 & 0.45 & 0.87 & 3.56 & 0.63 & 0.62 & 0.77 & 0.74 \\
\hline WYM (80 mm) & 143 & 149 & 59 & 286 & 0.71 & 0.66 & 2.07 & 0.44 & 0.49 & 0.83 & 0.67 \\
\hline VOL (500 mL) & 62 & 36 & 140 & 399 & 0.31 & 0.92 & 3.71 & 0.76 & 0.63 & 0.74 & 0.72 \\
\hline VESS (circumference) & 165 & 96 & 37 & 339 & 0.82 & 0.78 & 3.70 & 0.24 & 0.63 & 0.90 & $\underline{0.79}$ \\
\hline Colour (3) & 100 & 18 & 102 & 417 & 0.50 & 0.96 & 11.96 & 0.53 & 0.85 & 0.80 & $\underline{0.81}$ \\
\hline PI (0.69) & 108 & 184 & 94 & 251 & 0.53 & 0.58 & 1.26 & 0.81 & 0.37 & 0.73 & 0.56 \\
\hline $\mathrm{PI}(0.8)$ & 133 & 219 & 69 & 216 & 0.66 & 0.50 & 1.31 & 0.69 & 0.38 & 0.76 & 0.55 \\
\hline $\mathrm{PI}(1.0)$ & 161 & 278 & 41 & 157 & 0.80 & 0.36 & 1.25 & 0.56 & 0.37 & 0.79 & 0.50 \\
\hline RI (0.48) & 104 & 184 & 98 & 251 & 0.51 & 0.58 & 1.22 & 0.84 & 0.36 & 0.72 & 0.56 \\
\hline
\end{tabular}




\begin{tabular}{|c|c|c|c|c|c|c|c|c|c|c|c|}
\hline $\begin{array}{l}\text { Parameter (optimal } \\
\text { threshold) }\end{array}$ & TP & FP & FN & TN & SENS & SPEC & $\mathrm{LR}+$ & LR- & PPV & NPV & ACC \\
\hline RI (0.4) & 59 & 157 & 143 & 278 & 0.29 & 0.64 & 0.81 & 1.11 & 0.27 & 0.66 & 0.53 \\
\hline RI (0.5) & 117 & 197 & 85 & 238 & 0.58 & 0.55 & 1.28 & 0.77 & 0.37 & 0.74 & 0.56 \\
\hline PSV (58) & 3 & 1 & 199 & 434 & 0.01 & 1.00 & 6.46 & 0.99 & 0.75 & 0.69 & 0.69 \\
\hline TAMXV (18.45) & 23 & 14 & 179 & 421 & 0.11 & 0.97 & 3.54 & 0.92 & 0.62 & 0.70 & 0.70 \\
\hline VI (1.985) & 105 & 72 & $\mathrm{R}$ & 363 & 0.52 & 0.83 & 3.14 & 0.58 & 0.59 & 0.79 & 0.73 \\
\hline $\mathrm{FI}(41.7)$ & 21 & 21 & 181 & 414 & 0.10 & 0.95 & 2.15 & 0.94 & 0.50 & 0.70 & 0.68 \\
\hline VFI (2.25) & 50 & 16 & 152 & 419 & 0.25 & 0.96 & 6.73 & 0.78 & 0.76 & 0.73 & 0.74 \\
\hline
\end{tabular}

\begin{tabular}{|l|l|l|l|}
\hline \multicolumn{4}{|l|}{ Table 3. Comparing the diagnostic values of the parameters analyzed based on the area under the ROC curve } \\
\hline Parameter (optimal threshold) & AUROC & SE & $95 \%$ CI \\
\hline Age & 0.788 & 0.018 & $0.752-0.824$ \\
\hline BMI & 0.652 & 0.023 & $0.606-0.697$ \\
\hline MNP & 0.699 & 0.023 & $0.654-0.745$ \\
\hline Both sides & 0.683 & 0.024 & $0.636-0.731$ \\
\hline IOTA & 0.635 & 0.022 & $0.592-0.677$ \\
\hline PAP & 0.662 & 0.025 & $0.614-0.710$ \\
\hline Wym. & 0.683 & 0.023 & $0.638-0.727$ \\
\hline VOL & 0.714 & 0.022 & $0.671-0.758$ \\
\hline VESS & 0.788 & 0.020 & $0.748-0.828$ \\
\hline Colour & 0.831 & 0.020 & $0.793-0.870$ \\
\hline PI & 0.533 & 0.023 & $0.489-0.577$ \\
\hline RI & 0.522 & 0.023 & $0.478-0.567$ \\
\hline PSV & 0.589 & 0.023 & $0.544-0.634$ \\
\hline TAMXV & 0.661 & 0.022 & $0.617-0.705$ \\
\hline VI & 0.741 & 0.021 & $0.700-0.783$ \\
\hline FI & 0.651 & 0.022 & $0.607-0.695$ \\
\hline VFI & 0.741 & 0.021 & $0.700-0.783$ \\
\hline & & &
\end{tabular}

The highest values of the area under the ROC curve in a single variable analysis for ultrasound parameters were obtained for the "Colour" characteristic and flow indices in 3D ultrasound, i.e. VI and VFI (0.83).

\section{Discussion}

Ovarian cancer has the worse prognosis of all the reproductive system neoplasms. The bad prognosis of ovarian cancer is due to the fact that the disease is diagnosed too late, usually after it has already spread beyond the ovum. It is also related to the lack of specific symptoms in the early stages of the disease.

The most commonly used noninvasive imaging method in gynaecology is grayscale intravaginal ultrasound. The aim of this test is to search the tumour for suspicious morphological characteristics, i.e. endophytic growths, multicompartment or mixed cystic and solid structure. Bilateral location of such tumours suggests the existence of a malignant process. The $75 \%$ value of diagnostic precision (50\% sensitivity and $87 \%$ specificity) was obtained when the examined patient suffered from a bilateral tumour. For ultrasound morphology an accuracy a value of $64 \%$ ( $78 \%$ sensitivity and $57 \%$ specificity) was reached. If endophytic growths were present in the tumour, the diagnostic accuracy of the test amounted to $74 \%$ (45\% sensitivity and $87 \%$ specificity). Predictive values for these parameters suggest that they both initially classify adnexal tu- mours well. Not all authors agree with solid elements being a separate characteristic of a tumour. It has also been suggested that the evaluation of this element should be done with data describing echogenicity and the structure of the septum.

While introducing ultrasound imaging and gynaecology diagnostics, it was initially presumed that the size of the tumour was an important factor in differential diagnostics. A value of $67 \%$ for diagnostic accuracy $(71 \%$ sensitivity and $66 \%$ specificity) was obtained for the largest dimension of the tumour being $>8 \mathrm{~cm}$. For evaluation of volume $>500 \mathrm{~mL}$ the accuracy amounted to $72 \%$ (31\% sensitivity and $92 \%$ specificity).

Ultrasound examination with vessel flow imaging obtained with the colour Doppler method enables us to show increased vascularization and angiogenesis in most solid tumours. It was initially presumed that malignant tumours are characterized by a low-resistance flow reflected in $\mathrm{PI}(<0.8-$ $-1.0)$ and $\mathrm{RI}(<0.4-0.5)$ indices. Research showed, however, that the range of Doppler flow index variability is similar in both benign and malignant ovarian tumours [8-12].

The discriminant value for the pulsation index amounted to 0.69 . The diagnostic accuracy amounted to 5\% (53\% sensitivity and $58 \%$ specificity). For the resistance index RI with a threshold value of 0.48 the accuracy amounted to $56 \%$ (51\% sensitivity and 58\% specificity). Using the most often cited cutoff points in the literature, PI 0.8-1.0 and RI 0.4-0.5, does not confirm their usefulness in ovarian tumour differentiation [1, 11-13]. 
Attempting to answer the question of whether evaluation of the flow index in the examined tumour is useful, an evaluation of other parameters was proposed. One of those parameters is the location of vascularization in the examined adnexal tumour. Published data suggest that a peripheral layout of vessels in the tumour suggests benign lesions, whereas malignant lesions have one or more vessels located in the centre of the mass $[2,14]$. In the studied group a similar conclusion was reached. Diagnostic accuracy amounted to $79 \%$ ( $82 \%$ sensitivity and $78 \%$ specificity).

Another proposed characteristic differentiating adnexal tumours is the subjective evaluation of vascularization seen as colourized areas in colour ultrasound examination [1, $11,15,16,18]$. In the studied group of women the best discriminant value of the "Colour" characteristic was larger than 2 . The diagnostic accuracy amounted to $81 \%$, sensitivity amounted to $50 \%$, and specificity amounted to $96 \%$. This parameter obtained the highest value of the area underneath the ROC curve out of all the ultrasound parameters, and amounted to 0.831 .

Other parameters taken into consideration in the differential diagnostics of adnexal tumours we parameters of spectrum flow speed and its speed, among which were: peak systolic velocity (PSV) and time averaged maximum velocity (TAMXV) [15]. Analysis of prognostic values for parameters of flow speed evaluation shows their limited usefulness in preoperative differentiation of ovarian tumour malignancy, because the diagnostic accuracy for PSV amounted to $69 \%$, and $70 \%$ of TAMXV with low sensitivity percentages.
Rapid IT and ultrasound development enabled 3D reconstructions of the examined organs $[5,6,14]$. In a quantitative description of neovascularization in ovarian tumours, based on 3D ultrasound examination findings, flow and vascularization indices are used: $\mathrm{VI}, \mathrm{FI}, \mathrm{VFI}[5,14,19]$. It was concluded that these indices are more accurate in 3D than in 2D ultrasound. Diagnostic accuracy of VFI amounted to $74 \%$ (sensitivity $25 \%$, specificity $96 \%$ ), VI to $76 \%$ (sensitivity $52 \%$, specificity $83 \%$ ), and $\mathrm{FI}-68 \%$ (sensitivity $10 \%$ and specificity $95 \%$ ). The value of the area under the ROC curve amounted to 0.74 for $\mathrm{VFI}$ and $\mathrm{VI}$, and was lower for $\mathrm{FI}(0.65)$.

Performing the sonoangiogram exam in selected cases with 3D imaging enables a more precise evaluation of the tumour, and this way simplifies the process of qualifying the patient for a procedure [14].

\section{Conclusions}

The following parameters have to be considered in the initial differential diagnostics of adnexal tumours:

- semiquantitative evaluation of the "Colour" characteristic and location of vessels in the 2D colour Doppler ultrasound exam:

- morphological ultrasound evaluation of the tumour, with special consideration of endophytic growths larger than $3 \mathrm{~mm}$;

- evaluation of tumour volume;

- evaluation of vascular flow in 3D ultrasound with the usage of phonoangiography, and special consideration of the vascular index - VI and vascular-flow index VFI.

Source of funding: This work was funded by project no. 2 PO5E 06728.

Conflict of interest: The authors declare no conflict of interests.

\section{References}

1. Czekierdowski A. Badania nad angiogenezą w łagodnych i złośliwych guzach jajnika przy zastosowaniu ultrasonografii z kolorowym Dopplerem oraz oceny stężeń śródbłonkowego czynnika wzrostu i wybranych markerów nowotworowych, CA 125, CA 19.9, CA 72.4 i VEGF. Postdoctoral thesis. Ann UMCS Sect D 2002; LVII: 113.

2. Szpurek D. Ocena przydatności klinicznej indeksów sonomorfologicznych i dopplerowskich oraz antygenów CA-125 i TPS we wstępnej diagnostyce różnicowej guzów jajnika. Postdoctoral dissertation. Poznań: Wydawnictwo Akademii Medycznej w Poznaniu; 2004

3. Czekierdowski A. Diagnostyka ultrasonograficzna w raku jajnika. In: Markowska J, ed. Ginekologia onkologiczna. T. II. Wrocław: Elsevier Urban \& Partner; 2006: 819-833.

4. Dębski R. Ultrasonografia w ginekologii onkologicznej. In: Markowska J, ed. Ginekologia onkologiczna. T. I. Wrocław: Elsevier Urban \& Partner; 2006: 78-95.

5. Czekierdowski A, Smoleń A, Bednarek W, et al. Współczesna ultrasonografia w diagnostyce guzów jajnika: porównanie wartości predykcyjnych oceny morfologicznej, badania przepływu dopplerowskiego i obrazowania trójwymiarowego 3D. Ginekol Pol 2002; 76(11): 1061-1070.

6. Czekierdowski A, Kotarski J. Angiogeneza a ultrasonograficzna ocena przepływu krwi. In: Brązert J, Szaflik K, Pietryga M, et al., eds. Ultrasonografia dopplerowska w położnictwie i ginekologii. Poznań: OWN; 2004: 163-172.

7. Czekierdowski A. Zastosowanie ultrasonografii trójwymiarowej w różnicowaniu nowotworów jajnika. In: Brązert J, Szaflik K, Pietryga M, et al., eds. Ultrasonografia dopplerowska w położnictwie i ginekologii. Poznań: OWN; 2004: 185.

8. Alcázar JL, Castillo G. Comparison of 2-dimensional and 3-dimensional power-Doppler imaging in complex adnexal masses for the prediction of ovarian cancer. Am J Obstet Gynecol 2005; 192(3): 807-812.

9. Alcázar JL, Merce LT, Manero MG. Tree-dimensional power Doppler vascular sampling. A new method for prediction ovarian cancer in vascularized complex adnexal masses. J Ultrasound Med 2009; 28(3): 275-281.

10. Van Nagell JR, DePriest PD. Management of adnexal masses in postmenopausal women. Am J Obstet Gynecol 2005; 193(1): 30-35.

11. Smoleń A, Czekierdowski A, Stachowicz N, et al. Analiza unaczynienia guzów jajnika przy pomocy kolorowego i spektralnego Dopplera. Ann UMCS Sect D Cz. 5. 2004; 59(14): 85-91.

12. Smoleń A, Czekierdowski A, Stachowicz N, et al. Preoperative discrimination of adnexal masses in women: a comparison of the diagnostic value of selected clinical data and color doppler sonography. Pol J Environ Stud 2004; 13(2): 499-502.

13. Zalud I. Doppler evaluation of the ovary: clinical applications and challenges. Contemporary OB/Gyn. 2002; 147(3): 36-48.

14. Czekierdowski A, Stachowicz N, Smoleń A, et al. Zastosowanie ultrasonografii dopplerowskiej i sonoangiografii trójwymiarowej w badaniu unaczynienia i przepływu krwi w guzach przydatków macicy u kobiet. Ginekol Pol 2006; 77(4): $296-306$.

15. Valentin L. Gray scale sonography subjective evaluation of the color Doppler image and measurement of blood flow velocity for distinguishing benign and malignant tumors of suspected adnexal origin. Eur J Obstet Gynecol Reprod Biol 1997; 72(1): 63-72.

16. Timmerman D, Valentin L, Bourne $\mathrm{TH}$, et al. Terms, definitions and measurements to describe the sonographic features of adnexal tumors: a consensus opinion from the International Ovarian Tumor Analysis (IOTA) group. Ultrasound Obstet Gynecol 2000; 16(5): 500-505. 
17. Timmerman D. Lack of standardization in gynecological ultrasonography. Ultrasound Obstet Gynecol 2000; 16(5): 395-398.

18. Smoleń A, Czekierdowski A, Stachowicz N, et al. Przydatność badania ultrasonograficznego w skali szarości w różnicowaniu guzów przydatkowych u kobiet. Ann UMCS Sect D. Cz. 5. 2004; 59(14): 92-99.

19. Czekierdowski A, Stachowicz N, Smoleń A, et al. Three dimensional sonography as a secondary test for the differentiation of adnexal tumors detected in screening programs of ovarian malignancies. In: Gozdek N., Kotarski J., Polz-Dacewicz M., eds. Current health problems in empirical studies. Lublin: Werset; 2005: 271-276.

20. Czekierdowski A, Augustyniak S, Smoleń A. Ovarian tumor vascularity assessment with the use of 3D Power Doppler sonography and vascular blond flow indices measurements. Ultrasound Obstet Gynecol 2004; 24(1): 262-263.

Address for correspondence:

Agata Barbara Smoleń, MD, PhD, Assoc. Prof.

Katedra i Zakład Epidemiologii i Metodologii Badań Klinicznych UM

ul. Chodźki 1

20-093 Lublin

Polska

Tel.: +48 81 448-63-70

E-mail: agata.smolen@umlub.pl

Received: 29.04.2016

Revised: 23.05.2016

Accepted: 16.06.2016 